Łukasz Chyla, Justyna Glinka

Uniwersytet Jagielloński

Andrzej Szumański

Opiekun naukowy - Scientific Tutor

DOI: $10.19195 / 1733-5779.21 .6$

\title{
Zdatność arbitrażowa sporów uchwałowych w wybranych zagranicznych porządkach prawnych
}

\section{JEL Classification: K33}

Słowa kluczowe: zdatność arbitrażowa, spory korporacyjne, spory uchwałowe, arbitraż korporacyjny

Keywords: intra-corporate disputes, arbitrability, corporate arbitration

Abstrakt: Problem poddania sporów ze stosunku spółki kapitałowej pod kognicję sądów polubownych to jeden z najbardziej aktualnych problemów międzynarodowego arbitrażu handlowego. W niniejszym artykule przedstawione zostało ogólne podejście do prawa arbitrażowego oraz kwestii zdatności arbitrażowej w zagranicznych jurysdykcjach. Omówienie to posłuży przede wszystkim umiejscowieniu systemu polskiego w międzynarodowym arbitrażu handlowym i próbie odpowiedzi na pytanie, w jaki sposób ustawodawstwa poszczególnych państw rozwiązują problemy zaprezentowane w polskiej doktrynie i judykaturze. Szczególny nacisk został położony na system niemiecki - przez wzgląd na daleko idące podobieństwo do naszego systemu prawa handlowego — którego analiza może implikować podobne wnioski de lege lata i postulaty de lege ferenda dla polskiego ustawodawcy.

\section{Objective arbitrability of intra-corporate disputes in foreign legal systems}

Abstract: The aim of the article is to present one of the greatest controversy of international commercial arbitration, which is an objective arbitrability of corporate disputes. The article presents the comparative perspective on arbitrability in certain jurisdictions as well as legal barriers that prevent some corporate disputes from being fully subjected to arbitration proceedings by the parties (by an arbitration clause). Thorough analysis helps to identify the Polish approach amid international ones and propose certain solutions to challenges faced by Polish legislator. Due to all the similarities, the main emphasis is put on the analysis of German legal system, which can thus be used by Polish doctrine and judicature to successfully overcome some of the respective obstacles to be faced in the near future. 


\section{Wprowadzenie}

Postępująca globalizacja wraz z rosnącą potrzebą pewności obrotu gospodarczego sprawiły, że w zawiłych i skomplikowanych sporach korporacyjnych sądownictwo powszechne nie spełnia swojej roli. Przewlekłość postępowań, wątpliwości doktrynalne (np. odnośnie do charakteru prawnego uchwał walnego zgromadzenia akcjonariuszy), brak odrębnych sądów gospodarczych połączony z brakiem specjalistycznej wiedzy sędziów z zakresu ładu korporacyjnego (tzw. corporate governance) oraz dwuinstancyjność ścieżki sądowej sprawiają, że wymiar sprawiedliwości nie zapewnia dostatecznej gwarancji i ochrony prawnej spółkom kapitałowym.

Naturalnym remedium zdaje się w ostatnich latach arbitraż korporacyjny, coraz szerzej stosowany na całym świecie, zarówno w krajach kultury prawnej kontynentalnej, jak i common law. Szybkość i odformalizowanie arbitrażu, tajność postępowania, fachowość arbitrów (tzw. cachet behind the name) ${ }^{1}$, lecz także wysoka wykonywalność orzeczeń arbitrażowych sprawiają, że coraz więcej państw przyjmuje proarbitrażowe reformy.

W niektórych krajach wciąż jednak ma miejsce szeroko zakrojona dyskusja nad przyzwoleniem sądownictwu polubownemu orzekania w sporach korporacyjnych. Szczególne wątpliwości powstają w wypadku sporów o zaskarżanie uchwał organów kolegialnych (tzw. sporów uchwałowych), np. walnego zgromadzenia akcjonariuszy czy rady nadzorczej. Kontrowersje dotyczą przede wszystkim kwestii zdatności arbitrażowej tych sporów (definiowanej w wielu jurysdykcjach mniej lub bardziej niejasnym kryterium zdatności ugodowej), jak również problemu wielostronności sporu (tzw. multi-party disputes) czy rozszerzonej skuteczności wyroku sądu arbitrażowego.

W polskim porządku prawnym kwestia zdatności arbitrażowej sporów uchwałowych pozostaje przedmiotem wieloletnich kontrowersji, rozstrzyganych głównie na korzyść jej przeciwników. Zgodnie z art. 1157 k.p.c. ${ }^{2}$ zdatność arbitrażową można bowiem przyznać jedynie tym sporom, które posiadają jednocześnie zdatność ugodową. To niejasne kryterium oznacza, że zdatność arbitrażową mają wyłącznie te spory, w których strony mogą w pełni swobodnie rozporządzać swoimi uprawnieniami, co jest wątpliwe w wypadku sporów o podłożu korporacyjnym. Nie mamy tu bowiem do czynienia ze zwykłą sytuacją, gdzie dwie strony stosunku prawnego dysponują wzajemnymi uprawnieniami, ale $\mathrm{z}$ wieloma podmiotami (zgromadzenie wspólników lub walne zgromadzenie podejmujące sporną uchwałę, wspólnicy bądź akcjonariusze wytaczający powództwo przeciwko spółce oraz

${ }^{1}$ Zob. J.D.M. Lew, L.A. Mistelis, S.M. Kröll, Comparative International Commercial Arbitration, The Hague-London-New York 2003, s. 36-37.

2 Ustawa z dnia 17 listopada 1964 r. — Kodeks postępowania cywilnego, tekst jedn. (Dz.U. z 2014 r. poz. 101 z późn. zm.). 
spółka reprezentowana najczęściej przez zarząd), których możliwość do zawarcia ugody określonej treści pozostaje w związku z tym kontrowersyjna ${ }^{3}$.

Według niektórych przedstawicieli doktryny ${ }^{4}$ optujących za zdatnością arbitrażową omawianych sporów pomocna w tym względzie może okazać się właściwa interpretacja art. 1163 § 1 k.p.c. wskazującego explicite na dopuszczalność arbitrażu korporacyjnego $\mathrm{w}$ realiach polskich, pozornie kolizyjnego względem wspomnianego wcześniej art. 1157 k.p.c. Zgodnie z prezentowanym przez nich poglądem przepis ten stanowi lex specialis względem art. 1157 k.p.c., regulując zagadnienie zdatności arbitrażowej in extenso. Przemawiać miałyby za tym argumenty natury historycznej (przebieg prac legislacyjnych), systemowej oraz funkcjonalnej.

Jednak pomimo koncepcji, zgodnie z którą brak wyraźnego odniesienia art. 1157 k.p.c. do art. $1163 \S 1$ k.p.c. prowadzi do niejasnej relacji obu norm, która skutkować ma przyjęciem rozwiązania proarbitrażowego (favor arbitri), zarówno znaczna część doktryny ${ }^{5}$, jak i orzecznictwo ${ }^{6}$ wyraźnie odmówiły zastosowania art. $1163 \S 1$ k.p.c. jako przepisu szczególnego wobec art. 1157 k.p.c., dając temu drugiemu prymat w wyznaczeniu prawnych ram dla zdatności arbitrażowej sporów korporacyjnych.

Stawia to pod znakiem zapytania możliwość zastosowania arbitrażu korporacyjnego w praktyce ${ }^{7}$. Doniosłość problemu zawiera się w realnej groźbie utraty legitymacji czynnej do zaskarżenia wadliwej uchwały, w szczególności ze względu na upływ krótkich, liczonych w miesiącach, terminów zawitych dla powództw o uchylenie oraz stwierdzenie nieważności uchwał organów właścicielskich. Powstaje wówczas dwojakie ryzyko utraty owej legitymacji przez podmioty uprawnione (legitymowane w myśl art. 250 lub 422 § 2 k.s.h.) w razie istnienia zapisu na sąd polubowny. $Z$ jednej strony w razie uzyskania orzeczenia sądu arbitrażowego istnieje obawa, że w ramach stadiów postarbitrażowych zostanie ono uchylone (art. 1206 k.p.c.) lub sąd powszechny odmówi uznania bądź stwierdzenia jego wykonalności (art. 1214-1215 k.p.c.) właśnie ze względu na brak zdatności arbi-

${ }^{3}$ G. Suliński, Zdolność ugodowa sporów o zaskarżanie uchwat spółek kapitałowych, „ADR. Arbitraż i Mediacja" 2014, nr 3, s. 61-63; W. Jurcewicz, C. Wiśniewski, Zdatność arbitrażowa sporów korporacyjnych - perspektywa polska, „Przegląd Prawa Handlowego” (dalej: PPH) 2015, nr 10, s. 5.

4 A. Szumański, Dopuszczalność kognicji sądu polubownego w sprawach o zaskarżanie uchwat zgromadzeń spótek kapitałowych, [w:] Rozprawy prawnicze. Księga pamiatkowa Profesora Maksymiliana Pazdana, red. L. Ogiegła, W. Popiołek, M. Szpunar, Kraków 2005, s. 528, 534.

5 J. Ciszewski, T. Ereciński, Kodeks postępowania cywilnego. Komentarz, cz. 4. Przepisy z zakresu międzynarodowego postępowania cywilnego, cz. 5. Sąd polubowny (arbitrażowy), Warszawa 2006, s. 357-358.

${ }^{6}$ Uchwała SN z dnia 7 maja 2009 r., sygn. III CZP 13/09, OSNC 2010/1/9.

${ }^{7}$ R. Kos, Zdatność arbitrażowa sporów o ważność uchwat spółek kapitałowych, PPH 2014, nr 3, s. 28. 
trażowej. To samo dotyczy potencjalnej odmowy uznania i wykonania orzeczenia sądu polubownego za granicą. Z drugiej zaś strony - w wypadku skierowania sprawy na drogę sądownictwa powszechnego istnieje możliwość, że sąd, uznając swoją niewłaściwość (art. 1180 k.p.c.), odmówi wszczęcia sporu, a uprawniony wspólnik (akcjonariusz) z dużym prawdopodobieństwem utraci możliwość dochodzenia swoich praw przed sądem powszechnym. Wobec tego niepewność, czy dokonany zapis na sąd polubowny jest ważny i skuteczny oraz — w szczególności - czy obejmuje on spory uchwałowe, $w$ praktyce czynią postępowanie arbitrażowe - nie tylko w sprawach uchwałowych, lecz sprawach korporacyjnych w ogóle — wysoce ryzykownym.

\section{Tendencje światowe w zakresie prawa arbitrażowego}

Wiele państw rozpoznając prawidłowo najnowsze wyzwania prawa arbitrażowego, postanowiło ostatnimi czasy nowelizować swoje prawo arbitrażowe ${ }^{8}$. Poczynając od państw, z których w głównej mierze wywodzi się nasz system prawny, należy wskazać na Austrię, która zdecydowała się na taki krok w 2012 r. (chociaż właściwa nowelizacja miała miejsce w 2006 r.) oraz Francję — w 2011 r. W Niemczech z kolei już w 2009 r. wydane zostało przez Trybunał Federalny przełomowe orzeczenie „Zdatność Arbitrażowa II”, które pchnęło dyskusję nad szeroko pojętą zdatnością arbitrażową na nowe tory, otwierając drogę do przyznania sądom polubownym kognicji w sporach o zaskarżanie uchwał.

Przyglądając się natomiast pozostałym państwom, tytułem przykładu należy wymienić kraje, które najnowszych zmian na płaszczyźnie prawa arbitrażowego dokonały na przestrzeni ostatnich lat: Belgia reformowała swoje prawo w $2013 \mathrm{r}$., Singapur w 2012 r., Kolumbia w 2012 r., Hiszpania zaś w 2011 r. Podobna tendencja dotyczy stałych sądów arbitrażowych, których regulaminy również zostały poddane gruntownej rewizji w celu przystosowania do panujących realiów gospodarczych. Wśród nich, w kolejności od najbardziej rozpoznawalnych, wymienia się przede wszystkim: Regulamin UNCITRAL (2010 r.) oraz regulaminy: Szwajcarskiej Izby Handlowej ICC (w 2012 r.), Austriackiej Federalnej Izby Gospodarczej VIAC (w 2013 r.), Międzynarodowego Centrum Arbitrażowego w Hongkongu HIACK w 2013 r), Chińskiej Komisji Międzynarodowego Handlu CIETAC (w 2012 r.) oraz Międzynarodowego Centrum Arbitrażu w Singapurze SIAC (w 2013 r.). Na marginesie należy dodać, że ich śladem również rodzime

8 Analiza na podstawie: S.L. Brekoulakis, On arbitrability: Persisting Misconceptions and New Areas of Concern, [w:] Arbitrability: International and Comparative Perspectives, red. L.A. Mistelis, S.L. Brekoulakis, „International Arbitration Law Library” 19, Austin 2009, s. 19-45; oraz M. Orecki, Polskie przepisy o sądzie polubownym (arbitrażowym) - uwagi de lege ferenda, „Polski Proces Cywilny” 2014, nr 2, s. 198.

9 S.L. Brekoulakis, op. cit., s. 20. 
instytucje arbitrażowe dokonały zmian w swoich przepisach, m.in. Sąd Arbitrażowy przy Krajowej Izbie Gospodarczej (w 2014 r.) i Sąd Arbitrażowy Lewiatan (w 2012 r.).

Jest to w znacznej mierze efekt zjawiska tzw. forum shopping ${ }^{10}$, czyli konkurencji poszczególnych państw w celu ustanowienia norm jak najbardziej przyjaznych arbitrażowi. Taka potrzeba wynika zarówno ze względów ekonomicznych, jak i z konieczności wykreowania naturalnej przewagi celem zapewnienia lepszej ochrony rodzimym przedsiębiorcom w wypadku, gdy siedzibą miejsca arbitrażu jest kraj ojczysty.

Zauważalną powszechnie tendencją, zaczerpniętą z analizy prawnoporównawczej poszczególnych jurysdykcji, jest ogólna liberalizacja przepisów dotyczących zdatności arbirażowej ${ }^{11}$. Coraz częściej przyjmuje się interpretację wynikającą z konwencji międzynarodowych, że zdatność arbitrażowa powinna być zasadą, od której odstępstwa może wprowadzać jedynie sam ustawodawca (exceptiones non sunt extendendae) w wypadkach szczególnie uzasadnionych. Wszelkie wyjątki powinny być przy tym formułowane na tyle precyzyjnie i wąsko, by nie prowadziły do rozszerzającej interpretacji ograniczeń powszechnej zdatności arbitrażowej sporów.

\section{Zdatność arbitrażowa na tle regulacji międzynarodowych}

Definicji zdatności arbitrażowej próżno szukać w Konwencji genewskiej12. W Konwencji nowojorskiej ${ }^{13}$ pojęcie zdatności arbitrażowej wspomniane jest natomiast jedynie w art. II ust. $1^{14}$, w którym wskazuje się ją jako warunek skutecznego uznania umowy arbitrażowej, a także w art. V ust. 2 pkt a ${ }^{15}$, gdzie jej brak uznaje się za podstawę odmowy wykonalności i uznania wyroku sądu arbitrażowego.

10 Ibidem, s. 22.

11 D. Di Pietro, General Remarks on Arbitrability under the New York Convention, [w:] Arbitrability: International and Comparative Perspectives, red. L.A. Mistelis, S.L. Brekoulakis, „International Arbitration Law Library" 19, Austin 2009, s. 85-98.

12 Konwencja europejska o międzynarodowym arbitrażu handlowym, sporządzona w Genewie dnia 21 kwietnia 1961 r. (Dz.U. z 1964 r. Nr 40, poz. 270).

13 Konwencja o uznawaniu i wykonywaniu zagranicznych orzeczeń arbitrażowych, sporządzona w Nowym Jorku dnia 10 czerwca 1958 r. (Dz.U. z 1962 r. Nr 9, poz. 42).

14 „Każde z Umawiających się Państw uzna umowę pisemną, którą strony zobowiązują się poddać arbitrażowi wszystkie lub pewne spory, powstałe lub mogące powstać między nimi z określonego stosunku prawnego, zarówno umownego jak i pozaumownego, w sprawie, która może być rozstrzyganą w drodze arbitrażu".

15 „Odmowa uznania i wykonania orzeczenia arbitrażowego może nastąpić również i wówczas, jeżeli właściwa władza kraju, w którym postawiono żądanie uznania i wykonania, stwierdzi: a) że według prawa tego kraju przedmiot sporu nie może być rozstrzygany w drodze arbitrażu [...]”. 
Pewnej rekonstrukcji pojęcia zdatności arbitrażowej można dokonać na podstawie ustawy modelowej UNCITRAL z 1985 r. ${ }^{16}$, która stanowi, że każdy spór o charakterze handlowym (o podłożu umownym i pozaumownym) posiada zdatność arbitrażową (art. 1 ust. 1) ${ }^{17}$. Artykuł 7 ustawy modelowej pozwala natomiast na poddanie pod kognicję sądów arbitrażowych wszystkich sporów kontraktowych i pozakontraktowych. W piśmiennictwie zaznacza się, że przyjęcie przez państwo w drodze implementacji rozwiązań podobnych do tych zaproponowanych $\mathrm{w}$ prawie wzorcowym powinno w praktyce oznaczać liberalizację w zakresie zdatności arbitrażowej, poprzez przyznanie jej tym samym jak najszerszej kategorii sporów ${ }^{18}$.

W art. 1 ust. 5 ustawy modelowej dopuszczono możliwość ustanowienia w tym zakresie przez państwa pewnych ograniczeń, a tym samym odsunięcia sądownictwa polubownego od wybranych kategorii spraw, w których uznają swój monopol za właściwy ${ }^{19}$. Prawo modelowe przewiduje też wprowadzanie wyjątków nie tylko w ustawie recypowanej, lecz także w innych przepisach szczególnych. Biorąc to pod uwagę, jak również mając na względzie niewiążący, dobrowolny status ustawy modelowej, można postawić wniosek, że wprowadzanie ograniczeń do proponowanych rozwiązań nie napotyka żadnych przeszkód. Patrząc jednak na rozwój prawa arbitrażowego, obejmowanie zdatnością arbitrażową coraz większej liczby spraw stanowi obecnie silną tendencję światową i przyczyniło się już do wykształcenia koncepcji o ,śmierci niezdatności arbitrażowej" (the death of inarbitrability) ${ }^{20}$.

Pozostaje natomiast wątpliwe, czy Konwencja nowojorska wyznacza jakiekolwiek granice dowolności wyłączania zakresu zdatności arbitrażowej dla poszczególnych spraw. W doktrynie panuje pogląd, że interpretacja Konwencji w zakresie zdatności arbitrażowej powinna być traktowana rozszerzająco, a jej wyłączenie — zawężająco. Ewentualne wyjątki powinny być uzasadnione jedynie względami określonego krajowego porządku publicznego (public policy), które pozostają w zgodzie z celami Konwencji i praktyką innych państw sygnatariuszy ${ }^{21}$. Wyjątki te winny być przy tym sformułowane w taki sposób, aby nie zostały zinterpretowane zbyt obszernie. Podstawowym celem Konwencji jest bowiem harmonizacja zasad panujących w międzynarodowym prawie handlowym poprzez uczynienie

16 Ustawa modelowa o międzynarodowym arbitrażu handlowym uchwalona przez UNCITRAL w 1985 r., ze zmianami z 2006 r., http://www.uncitral.org/pdf/english/texts/arbitration/mlarb/07-86998_Ebook.pdf (dostęp: 15.01.2017).

17 R. Sikorski, Zagadnienia ogólne, [w:] Diagnoza arbitrażu. Funkcjonowanie prawa o arbitrażu i kierunki postulowanych zmian, red. B. Gessel-Kalinowska vel. Kalisz, Wrocław 2014, s. 43.

18 Ibidem, s. 41.

19 Ibidem.

${ }^{20}$ K. Youssef, The Death of Inarbitrability, [w:] Arbitrability..., s. 47-68.

${ }^{21}$ G.B. Born, International Commercial Arbitration, Alphen aan den Rijn 2009, s. 774-775. 
prostszą kwestii uznawania i wykonywania wyroków sądów polubownych. Zwraca się także uwagę na zaczerpniętą z Konwencji nowojorskiej zasadę niedyskryminacji (principle of non-discrimination), zgodnie z którą zaniechane powinny być przepisy poddające międzynarodowe klauzule arbitrażowe kryteriom surowszym niż tym dla umów krajowych.

Postulowane wyjątki od generalnej zasady zdatności arbitrażowej, zgodnie z praktyką Konwencji nowojorskiej, powinny być, po pierwsze, wprowadzane przede wszystkim w celu usprawiedliwionym okolicznościami, sytuacją społeczną i ekonomiczną oraz ochroną porządku publicznego. Po drugie, wyjątki te powinny być zgodne $\mathrm{z}$ tendencją panującą w większości państw-sygnatariuszy, a przede wszystkim nie powinny dyskryminować umów międzynarodowych o arbitraż.

\section{Zdatność arbitrażowa w świetle prawa niemieckiego}

Stan dyskusji w Niemczech sprzed 1998 r., a zatem przed wejściem w życie nowej regulacji prawa arbitrażowego ${ }^{22}$, przypominał stan obowiązujący obecnie w Polsce ${ }^{23}$. Zdatność arbitrażową miały zatem jedynie te spory, w przedmiocie których strony mogły zawrzeć ugodę (tzn. były do tego swobodnie uprawnione). Przeprowadzany przez judykaturę test zdatności ugodowej sporów uchwałowych determinował więc ewentualne przyznanie im zdatności arbitrażowej. W wyrokach z 1951 r. $^{24}$ oraz 1966 r. $^{25}$ Trybunał Federalny definitywnie odmówił zdatności arbitrażowej sporom uchwałowym, wyciągając taki wniosek z regulacji o wyłącznej właściwości sądu krajowego w miejscu siedziby spółki, która to regulacja wykluczałaby, zdaniem Trybunału, możliwość poddania sporu pod kognicję sądu polubownego ${ }^{26}$. W następnej odsłonie burzliwej dyskusji Sąd Krajowy w Hamm w 1986 r. uznał ${ }^{27}$, że zawarcie przez spółkę ugody w sprawie zgodności (bądź niezgodności) własnej uchwały z prawem jest wykluczone. Podniósł on wiele nowych w orzecznictwie - krytycznych dla zdatności arbitrażowej — argumentów dotyczących braku koncentracji postępowania oraz braku rozszerzonej prawomocności wyroku sądu ${ }^{28}$.

22 Zob. German Arbitration Act, oparta na ustawie modelowej UNCITRAL, http://sccinstitute. com/media/29988/german-arbitration-act.pdf (dostęp: 30.01.2017).

${ }^{23}$ K. Pörnbacher, A. Dolgorukow, Zdatność arbitrażowa sporów korporacyjnych (o zaskarżanie uchwat) - perspektywa niemiecka, PPH 2015, nr 10, s. 46.

24 Wyrok Trybunału Federalnego z dnia 4 lipca 1951 r., sygn. II ZR 117/50, MDR 1951, s. 674.

25 Wyrok Trybunału Federalnego z dnia 11 lipca 1966 r., sygn. II ZR 134/65, NJW 1966, s. 2055.

${ }^{26}$ K. Pörnbacher, A. Dolgorukow, op. cit., s. 47.

27 Wyrok Sądu Krajowego w Hamm z dnia 8 grudnia 1986 r., sygn. 8 U 73/86, NJW-RR 1987, s. $1319-1320$.

${ }^{28}$ K. Pörnbacher, A. Dolgorukow, op. cit., s. 47. 
Pierwszy prawdziwy przełom w kwestii przyznania zdatności arbitrażowej sporom uchwałowym nastąpił wraz z wydaniem przez Trybunał Federalny orzeczenia w 1996 r. $^{29}$, określanego powszechnie mianem „Zdatność arbitrażowa I”. Odmawiając mimo wszystko zdatności arbitrażowej tym sporom, Trybunał zaprezentował liczne argumenty zmieniające optykę dyskusji w tej sprawie. Stwierdził przede wszystkim, że spory o zaskarżanie uchwał w istocie posiadają obiektywną zdatność ugodową, ponieważ nie tylko sąd powszechny jest w stanie wywołać efekt nakazany przez prawo ${ }^{30}$. Mogą tego dokonać także sami wspólnicy, jako że swoim zgodnym współdziałaniem są władni uchylić uchwałę będącą przedmiotem sporu (actus contrarius), co będzie równoznaczne $\mathrm{z}$ wycofaniem jej z obrotu prawnego $^{31}$. Na drodze do uznania przez Trybunał zdatności arbitrażowej sporów stanęła kwestia braku koncentracji postępowania w wypadku zaskarżenia uchwały przez kilku wspólników, a co ważniejsze — również braku przyznania rozszerzonej skuteczności wyrokom sądów polubownych na wzór niemieckich przepisów o spółce akcyjnej (Aktiengesetz) ${ }^{32}$. Rozciągnięcie skutków wyroku na osoby mogące, a niebiorące udziału w procesie wymagałoby zatem, zdaniem Trybunału, upoważnienia ustawowego ${ }^{33}$. Niemożność osiągnięcia takiego skutku wolą stron zawartą w umowie wspólników lub statucie spółki stała więc na drodze przyznania zdatności arbitrażowej sporom uchwałowym ${ }^{34}$.

Wejście w życie nowelizacji kodeksu postępowania cywilnego (ZPO) ${ }^{35} \mathrm{w} 1998 \mathrm{r}$. pchnęło całą dyskusję na nowe tory. Obowiązujący do dziś art. 1030 ust. 1 ZPO stanowi, że orzecznictwu sądu arbitrażowego mogą być poddane roszczenia o charakterze majątkowym ${ }^{36}$. Te o charakterze niemajątkowym ${ }^{37}$ mogą natomiast być przedmiotem zapisu na sąd polubowny tylko w wypadku, gdy strony uprawnione są do zawarcia ugody co do przedmiotu sporu. Rozwiązanie to, tylko z pozoru podobne do regulacji polskiej, wprowadza kryterium zdatności ugodowej jedynie dla sporów dotyczących roszczeń o charakterze niemajątkowym. Ponadto kodeks nie-

29 Wyrok Trybunału Federalnego z dnia 29 marca 1996 r., sygn. II ZR 124/95, NJW 1996, s. 1753 .

30 K. Pörnbacher, A. Dolgorukow, op. cit., s. 48.

31 Wyrok Trybunału Federalnego z dnia 29 marca 1996 r., nb. 12.

32 Zob. art. 248 ust. 1 niemieckiej ustawy o spółce akcyjnej (AktG), https://www.gesetze-iminternet.de/bundesrecht/aktg/gesamt.pdf (dostęp: 30.01.22017).

33 Wyrok Trybunału Federalnego z dnia 29 marca 1996 r., nb. 14-15.

34 J. Bredow, Arbitrating Shareholder Resolution Disputes in Germany: The New DIS-Supplementary Rules for Corporate Law Disputes ('DIS-SRCoLD'), [w:] Księga pamiatkowa 60-lecia Sądu Arbitrażowego przy Krajowej Izbie Gospodarczej, red. J. Okolski et al., Warszawa 2010, s. 471.

35 Niemiecki kodeks postępowania cywilnego (Zivilprozessordnung/Zivilverfahrensgesetzbuch, ZPO), https://www.gesetze-im-internet.de/bundesrecht/zpo/gesamt.pdf [dostęp: 30.01.2017]).

${ }^{36}$ Niem. jeder vermögensrechtlicher Anspruch.

37 Niem. nicht vermögensrechtliche Anspruche. 
miecki posługuje się terminem ,,roszczenia” (a nie ,prawa”, jak art. 1157 polskiego k.p.c.), którego pole znaczeniowe podobne jest raczej do ,przedmiotu sporu"38.

W Niemczech, podobnie jak w Polsce, nie funkcjonuje legalna definicja roszczeń majątkowych. O ile jednak w naszym kraju kwestia majątkowości praw korporacyjnych bywała przedmiotem wątpliwości, o tyle w prawie niemieckim kwestia ta jest zasadniczo bezsporna ${ }^{39}$.

Pomimo odstąpienia od kryterium zdatności ugodowej w przypadku sporów korporacyjnych oraz znacznej liberalizacji wprowadzonej nową regulacją, zastrzeżenia wymienione w wyroku z 1996 r. („Zdatność Arbitrażowa I’) całkowicie blokowały arbitraż handlowy w tych sprawach. Zmiana nastąpiła dopiero w 2009 r., kiedy Trybunał Federalny wyrokiem zwanym „Zdatność arbitrażowa II" ${ }^{40}$ dokonał prawdziwego przełomu, przyznając sporom polubownym potencjalną kompetencję do orzekania w sprawach o zaskarżanie uchwał spółek z o.o. $(\mathrm{GmbH})^{41}$. W braku jednak ,standardów minimalnych” w samej znowelizowanej ustawie powinny one być bezwzględnie zawarte w klauzuli arbitrażowej ${ }^{42}$. Dla realizacji powyższego Trybunał wyodrębnił cztery główne kryteria warunkujące ważność klauzuli arbitrażowej ${ }^{43}$.

Zgodnie z pierwszym z nich wszyscy wspólnicy muszą jednomyślnie związać się klauzulą arbitrażową, czego można dokonać albo bezpośrednio w umowie (statucie) spółki, albo w osobnej umowie ${ }^{44}$. Po drugie, wszystkie podmioty w spółce (wliczając w to wspólników, organy i ich członków) powinny zostać odpowiednio poinformowane o istniejącym postępowaniu arbitrażowym, co miałoby jednocześnie umożliwić im przystąpienie do jednej ze stron w charakterze interwenienta ubocznego. Po trzecie, wszyscy przystępujący zgodnie z powyższym do udziału w sporze powinni mieć możliwość czynnego uczestniczenia w wyborze arbitra. Uprawnienie to może zostać wyłączone jedynie poprzez przekazanie kompetencji do wyboru arbitra podmiotowi trzeciemu, niezależnemu od spółki (np. instytucji neutralnej, organowi organizacyjnemu stałego sądu arbitrażowego) ${ }^{45}$. Ostatnim kryterium wyszczególnionym przez Trybunał jest postulowane już wcześniej (m.in. w wyrokach Sądu Krajowego w Hamm z 1986 r. i Trybunału Federalnego z 1996 r.) zapewnienie mocą klauzuli arbitrażowej koncentracji procesowej, co

38 A. Budniak, Charakter prawny oraz dopuszczalność zawarcia zapisu na sad polubowny w prawie polskim i niemieckim, cz. II, „Rejent” 2008, nr 10, s. 68.

39 K. Pörnbacher, A. Dolgorukow, op. cit., s. 48.

40 Wyrok Trybunału Federalnego z dnia 6 kwietnia 2009 r., sygn. II ZR 255/08, BGHZ 180.

41 Niem. Gesellschaft mit beschränkter Haftung.

42 K. Pörnbacher, A. Dolgorukow, op. cit., s. 49.

43 Ibidem, s. 49-51.

44 Wyrok Trybunału Federalnego z dnia 6 kwietnia 2009 r., nb. 15.

45 Trybunał przyjął, że wybór arbitrów nie wymaga osiągnięcia konsensusu przez wszystkich zainteresowanych, co prima facie stoi w sprzeczności z zasadą jednomyślności obowiązującą w postępowaniu arbitrażowym; ibidem. 
oznacza, że spory o zaskarżanie tej samej uchwały będą łącznie rozpoznawane przez ten sam sąd arbitrażowy (zespół orzekający) ${ }^{46}$.

Obecnie stan dyskusji nad zdatnością arbitrażową sporów o zaskarżanie uchwał dotyczy problematyki spełnienia kryteriów, jakie Trybunał Federalny uznał za kluczowe dla przyznania kognicji sądom arbitrażowym ${ }^{47}$. W tym kontekście wskazuje się przede wszystkim na problem dopasowania starych, najczęściej nieskutecznych klauzul arbitrażowych w istniejących już spółkach do kryteriów określonych w wyroku „Zdatność Arbitrażowa II”48. Niemniej istotna okazuje się kwestia sankcji nieważności w wypadku niespełniania przez klauzulę arbitrażową standardów wyznaczonych przez Trybuna1 ${ }^{49}$. Zdaniem komentujących nadmierny rygoryzm stanowi ona rozwiązanie niewspółmierne, w szczególności dlatego że wymagane gwarancje mogą być zapewnione na wiele innych sposobów, różniących się od proponowanego modelu ochrony pozostałych wspólników ${ }^{50}$.

$\mathrm{Na}$ marginesie warto wspomnieć, że w odpowiedzi na powyższe najbardziej rozpoznawalna niemiecka instytucja arbitrażowa, tzw. DIS (Niemiecki Instytut Sądownictwa Arbitrażowego) ${ }^{51}$, opracowała dodatkowy (specjalny) regulamin uzupełniający, dotyczący stricte spraw wynikłych ze stosunku spółki, czyli tzw. DIS-SRCoLD ${ }^{52}$ (DIS Supplementary Rules for Corporate Law Disputes) ${ }^{53}$. Dokument był konsultowany z sędziami Trybunału Federalnego i spełnia wszelkie wymogi określone w orzeczeniu „Zdatność Arbitrażowa II"54 . Biorąc pod uwagę, jak łatwo o błąd przy zapewnieniu prawidłowej procedury w klauzuli arbitrażowej, lecz także mając na względzie zagrożenie płynące $\mathrm{z}$ sankcji nieważności w przypadku jej wadliwego sformułowania, skorzystanie z Instytutu DIS i jej

46 Wyrok z dnia 6 kwietnia 2009 r., nb. 20.

47 K. Pörnbacher, A. Dolgorukow, op. cit., s. 53-56.

48 Pierwsza klauzula arbitrażowa wymaga jednomyślności. Nie jest natomiast sprecyzowane, czy istniejące klauzule mogą być dopasowane do nowych wymogów w formie uchwały podjętej większością trzech czwartych głosów, wymaganej dla spraw ważnych. Zob. też K. Pörnbacher, S. Baur, [w:] K.L. Mehrbrey, Handbuch Gesellschaftsrechtliche Streitigkeiten, Köln 2013, nb. 196200, s. 19; oraz H. Raeschke-Kessler, [w:] M. Habersack, P. Hommelhoff, Festschrift für Wulf Goette zum 65. Geburtstag, München 2011, s. 394.

49 Dominuje pogląd, że wady klauzul nie tylko nie mogą być sanowane drogą wykładni uzupełniającej, lecz także ich zgodność z wytycznymi jest oceniana w sposób abstrakcyjny i sztywny, nieuwzględniający okoliczności konkretnego stanu faktycznego. Zob. K. Pörnbacher, A. Dolgorukow, op. cit., s. 54.

50 Ibidem.

51 Niem. Die Deutsche Institution für Schiedsgerichtsbarkeit.

52 Zob. J. Bredow, op. cit., s. 471; oraz K. Pörnbacher, A. Dolgorukow, op. cit., s. 51.

53 DIS-Supplementary Rules for Corporate Law Disputes 09 (SRCoLD) obowiązujące od 16 września 2009 r., http://disarb.org/de/16/regeln/dis-supplementary-rules-for-corporate-law-disputes-09-srcold-id15 [dostęp: 30.01.2017]).

${ }^{54}$ K. Schwedt, Die praktische Umsetzung der BGH-Urteile Schiedsfähigkeit I und II, ,Zeitschrift für Schiedsverfahren (SchiedsVZ)" 2010, s. 166; K. Pörnbacher, A. Dolgorukow, op. cit., s. 52 . 
reguł DIS-SRCoLD jest rozwiązaniem optymalnym i powszechnie w Niemczech praktykowanym. Zapewnia ono zarówno szybkość, odformalizowanie oraz poufność postępowania, jak i pewność obrotu gospodarczego czy brak ryzyka uchylenia wyroku w późniejszych stadiach postarbitrażowych.

\section{Zdatność arbitrażowa w świetle prawa francuskiego}

W niniejszych rozważaniach warto uwzględnić Francję jako kraj tradycyjnie uchodzący za miejsce przychylne arbitrażowi, zarówno przez wzgląd na bogate orzecznictwo, jak i wypracowane przez doktrynę i judykaturę nowoczesne podejście do kwestii zdatności arbitrażowej sporów (w tym korporacyjnych).

Zdatność arbitrażową we Francji regulują przepisy Code Civil ${ }^{55}$. Zgodnie z art. 2059 tejże ustawy: ,każdy może rozstrzygnąć w arbitrażu spory o roszczenia, którymi w pełni dysponuje"56. Z kolei zgodnie z art. 2060 ust. 1: „nie można zawrzeć umowy arbitrażowej w sprawach związanych ze zdolnością prawną podmiotu, dotyczących rozwodu i separacji, dotyczących podmiotów publicznych oraz ogółem, we wszystkich sprawach dotyczących porządku publicznego"57.

Francuskie pojęcie klauzuli porządku publicznego zasadniczo różni się od polskiego odpowiednika. Polega ono na przyporządkowaniu wybranych kategorii prawa materialnego do „obszaru porządku publicznego" "58, nie opierając się tym samym na pojęciach ,podstawowych zasad porządku prawnego” lub „rażącego naruszenia prawa", jak ma to miejsce w Polsce. Ponadto zaliczenie danej sprawy do sfery porządku publicznego powoduje brak zdatności arbitrażowej sporu, a nie tylko możliwość kontroli sądowej w stadium postarbitrażowym. Wyłączenie więc kognicji sądów arbitrażowych w odniesieniu do określonych sporów zależy stricte od tego, czy doktryna wraz z orzecznictwem zdecydowały o zakwalifikowaniu danego zagadnienia do sfery porządku publicznego, co jednakże budziło znaczne kontrowersje na przestrzeni lat ${ }^{59}$.

Od czasu dekretu o arbitrażu międzynarodowym z 1980 r. ${ }^{60}$, który zliberalizował podejście do ograniczeń wynikających z Code Civi1 ${ }^{61}$, Francja uchodzi za kraj

55 Kodeks cywilny Francji, https://www.legifrance.gouv.fr/content/download/1950/13681/version/3/file/Code_22.pdf (dostęp: 30.01.2017).

56 M.P.P. Viscasillas, Arbitrability of (Intra-) Corporate Disputes, [w:] Arbitrability..., s. 274. Jeżeli nie podano inaczej, tłum. własne.

57 Ibidem.

58 A.W. Wiśniewski, Międzynarodowy arbitraż handlowy w Polsce. Status prawny arbitrażu i arbitrów, Warszawa 2011, s. 245.

59 Ibidem, s. 244.

60 Dekret Ministra Sprawiedliwości z dnia 13 stycznia 2011 r., nr 2011-48, portant reforme de l'arbitrage, NOR: JUSC1025421D, zmieniający w całości Księgę IV francuskiego Kodeksu postępowania cywilnego.

${ }^{61}$ E. Gaillard, J. Edelstein, [w:] Practitioner's Handbook on International Commercial Arbitration, red. F.B. Weigand, München 2002, s. 648-649, 671-672. 
generalnie przyjazny arbitrażowi - szczególnie w materii porządku publicznego dotyczącego spraw międzynarodowych. W francuskiej doktrynie panuje pogląd, że międzynarodowy arbitraż wypracował własny system zasad dotyczący porządku publicznego, który co do zasady nie wymaga ingerencji ze strony orzecznictwa sądów francuskich.

Podobnie do wielu innych państw zachodniej Europy, również Francja zdecydowała się ostatnimi czasy na reformę prawa arbitrażowego ${ }^{62}$. Śladem Szwajcarii, nowa regulacja wprowadza przepis, który daje stronom możliwość zrzeczenia się prawa do skarżenia wyroków sądów polubownych. Regulacja podtrzymuje też nastawienie przychylne arbitrażowi i międzynarodowym inwestorom, w sposób innowacyjny podkreślając elastyczne podejście do kwestii arbitrażu międzynarodowego ${ }^{63}$. Przepisy francuskie nie wprowadzają także rozróżnienia na prawa majątkowe i niemajątkowe, zakładając w braku odmiennego postanowienia możliwość pełnego dysponowania roszczeniami w kontekście wszystkich rodzajów praw i roszczeń.

Na marginesie należy przypomnieć, że klasyczne ujęcie porządku publicznego było we Francji bardzo szerokie, co przekładało się pośrednio na poważne ograniczenie zdatności arbitrażowej przez dorobek orzecznictwa. Zmiana podejścia w tym zakresie zachodziła paralelnie w doktrynie i judykaturze, która ostatecznie dokonała wspomnianego już rozróżnienia na sprawy krajowe i międzynarodowe, przy znacznym uwolnieniu tych drugich od ograniczeń wynikających z wewnętrznych przepisów dotyczących sfery tzw. porządku publicznego. Aktualnie powszechną aprobatę uzyskał pogląd, w myśl którego wyłączenie zdatności arbitrażowej we francuskim systemie prawnym może mieć miejsce jedynie na skutek wyraźnego zastrzeżenia przewidzianego w przepisach prawa.

\section{Zdatność arbitrażowa w świetle prawa austriackiego}

Rozwiązania austriackie, tradycyjnie zbliżone do konstrukcji obecnych w porządku niemieckim, wykształciły znacznie bardziej liberalne podejście w kwestii zdatności arbitrażowej sporów o zaskarżanie uchwał wspólników. Stało się to za sprawą bogatego orzecznictwa ${ }^{64}$, które dopuszczało zdatność arbitrażową spo-

621 maja 2011 r. weszła w życie, długo oczekiwana przez praktyków we Francji, reforma francuskiego prawa arbitrażowego, stanowiąca art. 1442-1527 francuskiego Kodeksu postępowania cywilnego (była to pierwsza zmiana od 1980 r.).

63 E. Gaillard, France adopts new law on arbitration, „New York Law Journal” 245, 24.01.2011, nr 15.

${ }^{64}$ Wyrok OGH z dnia 3 czerwca 1950 r., docket no. 2 Ob 276/50; wyrok OGH z dnia 10 października 1999 r., docket no. 7 Ob 221/98w, RdW 206 (1999); wyrok OGH z dnia 3 kwietnia 2001 r., docket no. 4 Ob 37/01x, ecolex 350 (2001); wyrok OGH z dnia 29 czerwca 2006 r., docket no. 6 Ob 145/06a, RdW 588 (2006). 
rów uchwałowych w odniesieniu do spółek z ograniczoną odpowiedzialnością 65 pomimo funkcjonowania w prawie austriackim kryterium zdatności ugodowej ukształtowanej na wzór prawa niemieckiego.

Dalsza liberalizacja prawa na omawianej płaszczyźnie dokonała się wraz $\mathrm{z}$ porzuceniem testu ugodowości sporów, co nastąpiło $\mathrm{w}$ drodze reformy prawa arbitrażowego z 2006 r. ${ }^{66}$, która poprzez art. 582 ZPO wprowadziła generalną zdatność arbitrażową wszelkich sporów o charakterze majątkowym. Miało to na celu realizację postulatów o pełnej implementacji zasad UNCITRAL Model Laws.

Ponadto urzędowy komentarz do wprowadzonej regulacji wyraźnie określił zasadę obiektywnej zdatności arbitrażowej sporów korporacyjnych, podkreślając przy tym praktyczne problemy wynikające ze specyfiki tych sporów, zwłaszcza dotyczące braku rozszerzonej prawomocności wyroku sądu polubownego ${ }^{67}$. Rozciągnięcie skutków wyroku sądu państwowego na pozostałych wspólników znajdowało umocowanie w art. 42 ustawy o spółkach z ograniczoną odpowiedzialnością (GmbH-Gesetz) oraz w art. 197 ustawy o spółkach akcyjnych (Aktiengesetz). Nowa regulacja została również przedmiotem licznego liberalnego orzecznictwa sądownictwa austriackiego ${ }^{68}$.

Co nie mniej znaczące, mimo że niemiecka ustawa z 1998 r. leżała u podstaw nowelizacji austriackiej uchwalonej niemal 10 lat później, zdatność arbitrażowa została przyznana sporom uchwałowym przez orzecznictwo niemieckie dopiero wyrokiem Trybunału Federalnego ,Zdatność Arbitrażowa II” w 2009 r., i to tylko w kontekście sporów ze stosunku spółki z o.o. Tymczasem pod reżimem prawa austriackiego stan taki, powodowany przychylnym orzecznictwem, utrzymywał się na długo przed ustawowym unormowaniem problemu.

Konkludując, na gruncie doktryny i orzecznictwa austriackiego zdatność arbitrażowa sporów nie stanowi przedmiotu kontrowersji zarówno w przypadku spółki z o.o., jak i spółki akcyjnej. Aby natomiast zapewnić pełną wykonalność wyroków sądów polubownych, bez osobnego rozciągania przez sąd powszechny skutków wyroku na osoby trzecie i pozostałych wspólników, każdy wspólnik powinien być związany umową arbitrażową, uczestniczyć w wyborze zespołu orzekającego oraz uzyskać w procesie przed sądem polubownym status strony, a nie jedynie interwenienta ubocznego.

65 C. Koller, Par. 3/90, [w:] Schiedsverfahrensrecht, red. C. Liebscher, P. Oberhammer, W.H. Rechberger, Wien 2011; oraz A. Fremuth-Wolf, [w:] Arbitration Law of Austria: Practice and Procedure, red. S. Riegler, New York 2007, s. 121.

${ }^{66}$ Ustawa z dnia 1 lipca 2006 r., zmieniająca art. 577-618 austriackiego Kodeksu postępowania cywilnego (ZPO), Schiedsrechts Änderungsgesetz 2006, BGB1 I 2006/7.

67 A.W. Wiśniewski, op. cit., s. 250.

${ }^{68}$ Wyrok OGH z dnia 22 października 2010 r., docket no. 7 Ob 103/10p, GeS. 276 (2010); wyrok OGH z dnia 19 kwietnia 2012 r., docket no. 6 Ob 42/12p, GeS 388 (2012); wyrok OGH z dnia 8 maja 2013 r., docket no. 6 Ob 47/13z, RS0045066. 
Chcąc uniknąc błędów i niespodzianek, w praktyce umów arbitrażowych proponuje się następujące postanowienia zapisu na sąd polubowny, które zapewnią utrzymanie go w mocy ${ }^{69}$ :

— obowiązek spółki do poinformowania wszystkich potencjalnych stron o wytoczeniu powództwa ze stosunku spółki;

- ustanowienie wyraźnego terminu na dołączenie do procesu w charakterze strony;

— delegowanie kompetencji do wyboru zespołu orzekającego podmiotowi trzeciemu, niezależnemu od spółki.

\section{Zdatność arbitrażowa w świetle prawa szwajcarskiego}

Szwajcarski system prawa arbitrażowego uchodzi powszechnie za jeden z najbardziej liberalnych i przyjaznych arbitrażowi w Europie ${ }^{70}$. Warto przy tym zaznaczyć, że Szwajcaria już od 1987 r. odrzuciła rozróżnienie praw o charakterze majątkowym na takie, którymi strony mogą swobodnie dysponować, i takie, którymi dysponowanie poddane jest limitacji ${ }^{71}$. Co ciekawe, nawet wcześniej kognicja sądów polubownych w sprawach o zaskarżanie uchwał zgromadzeń wspólników nie była kwestionowana ${ }^{72}$.

Kwestia zdatności arbitrażowej jest tam uregulowana szwajcarską ustawą o prawie prywatnym międzynarodowym (SPIL) ${ }^{73}$, która znajduje zastosowanie do każdego arbitrażu międzynarodowego z miejscem prowadzenia sporu w Szwajcarii. Artykuł 177 ust. 1 SPIL stanowi: „każdy spór dotyczący roszczeń majątkowych może być poddany arbitrażowi".

Samo pojęcie roszczenia majątkowego rozumiane jest tu natomiast bardzo szeroko, co wynika z postulatów liberalizacji prawa. Orzecznictwo szwajcarskich sądów wskazuje, że poddane arbitrażowi mogą być wszystkie sprawy mające wartość pieniężną ${ }^{74}$. Doktryna szwajcarska twierdzi wprost, że zdatnością arbitrażową cieszą się wszelkie spory korporacyjne (w tym te dotyczące zaskarżania uchwał), pod warunkiem wszakże zamieszczenia klauzuli arbitrażowej w umowie wspólników (statucie spółki ${ }^{75}$.

69 N. Pitkowitz, Die Aufhebung von Schiedssprüchen, Verschiedenes, Wien 2008, par. 371.

70 A.W. Wiśniewski, op. cit., s. 246.

71 Ibidem.

72 G. Walter, W. Busch, J. Brönnimann, Internationale Schiedsgerichtsbarkeit in der Schweiz, Berno 1991, s. 54-62.

73 Swiss Private International Law Statute (1990), http://mitchellhamline.edu/wp-content/ uploads/sites/18/2016/05/DOC-10-Swiss-Private-International-Law-Statute.pdf (dostęp: 30.01.2017).

74 Orzeczenie Swiss Federal Tribunal z dnia 23 czerwca 1992 r. w sprawie Fincantieri-Cantieri Navali Italiani SpA v. M and Arbitration Tribunal, XX YBCA 766 (1995).

75 A.K. Schnyder, Das neue IPR-Gesetz, Zürich 1990, s. 145. 


\section{Zdatność arbitrażowa w świetle prawa włoskiego}

Nowatorskie rozwiązanie można odnaleźć, analizując włoski ustrój prawny. Obecnie funkcjonujące w Polsce ograniczenie zdatności arbitrażowej sporów poprzez ustanowienie kryterium zdatności ugodowej można przyrównać do systemu funkcjonującego we Włoszech przed wprowadzeniem gruntownych zmian dekretem $\mathrm{nr} 5 \mathrm{z} 17$ stycznia $2003 \mathrm{r}^{76}$

Tamtejszy art. 806 Kodeksu cywilnego stanowił, że spory, których strony nie mogą rozstrzygnąć w drodze ugody, nie mogą być poddane arbitrażowi. W praktyce oznaczało to tradycyjne odmówienie sporom uchwałowym przymiotu zdatności arbitrażowej. Przy podobnym stanie regulacji w Polsce zwolennicy odmiennego podejścia próbują argumentować za przyznaniem art. 1163 k.p.c. statusu lex specialis względem art. 1157 k.p.c.

W celu przeciwdziałania blokowaniu arbitrażu korporacyjnego przez obstrukcyjną powolność włoskiego systemu sądownictwa powszechnego (gdzie rekordowe wyroki zapadały po kilkunastu latach od wszczęcia postępowania) oraz w odpowiedzi na liczne apele środowisk gospodarczych wprowadzono innowacyjną regulację mającą na celu wyeliminowanie dotychczasowych przeszkód dla arbitrażu w sporach korporacyjnych.

Wspomniany dekret z 2003 r. dopuścił expressis verbis zdatność arbitrażową sporów ze stosunku spółki, w tym sporów uchwałowych ${ }^{77}$. Artykuły 34-37 wskazanego dekretu wprowadzają odstępstwa od generalnego reżimu kodeksu cywilnego, regulując przy tym szczegółowo warunki i zasady, na jakich miałoby się odbywać orzekanie w tym zakresie przez sądy polubowne. Zasady te znajdują zastosowanie wyłącznie w sytuacji, gdy zarówno siedzibę spółki, jak i miejsce arbitrażu stanowią Włochy ${ }^{78}$.

Do typowych postanowień rzeczonego dekretu należą m.in. ${ }^{79}$ :

— związanie klauzulą arbitrażową spółki i wszystkich wspólników (o ile zawarta jest $w$ umowie spółki);

— wymóg określenia przez klauzulę szczegółowego trybu powołania zespołu orzekającego;

— wymóg ujawnienia postępowania w rejestrze przedsiębiorców;

- możliwość przystąpienia do postępowania przez wspólników w charakterze interwenientów głównych oraz osób trzecich w charakterze interwenientów ubocznych.

${ }^{76}$ F.M. Buonaiuti, L'arbitrabilita delle controversie nella riforma del diritto societario, tra arbitrato interno e arbitrato internazionale, ,Rivista dell“Arbitrato” 2003, $\mathrm{nr} 1$.

$77 \mathrm{~W}$ prawie włoskim tzw. delibere assembleari.

78 A. Anglani, F. Liguori, Italy's new arbitration laws, „The European Arbitration Review” 2007, http://globalarbitrationreview.com/edition/1000463/the-european-arbitration-review-2017, s. 49.

79 Ibidem, s. 46-49. 
Do oryginalnych rozwiązań narzuconych dekretem należą natomiast ${ }^{80}$ :

— rygor nieważności klauzuli w przypadku nieoddania wyboru zespołu orzekającego podmiotowi zewnętrznemu względem spółki;

— zakaz orzekania na zasadach słuszności (tylko zgodnie z obowiązującymi przepisami prawa);

- zakaz wyłączenia skargi o uchylenie wyroku do sądu państwowego (bez względu na to, czy jest to arbitraż krajowy, czy międzynarodowy).

Ponadto należy zauważyć, że dekret nie uwzględnia powyższej zdatności arbitrażowej w odniesieniu do akcyjnych spółek publicznych, co wyłącza możliwość zawierania klauzul arbitrażowych w statutach tych spółek, a w praktyce dostępność arbitrażu w ogóle. Spotkało się to z krytyką włoskiego piśmiennictwa ${ }^{81}$, które podejmuje próby uzasadnienia poddania sporów uchwałowych w spółkach publicznych sądom arbitrażowym na zasadach ogólnych ${ }^{82}$. Ograniczenie to wiąże się przede wszystkim z obawą przed konsekwencjami dla sprawności postępowania wynikającymi z dużego rozdrobnienia akcjonariatu.

W efekcie włoskie rozwiązanie uchodzi za nowoczesne, choć nadto sformalizowane. Zdaniem Andrzeja W. Wiśniewskiego ,włoskiemu ustawodawcy udało się rozbroić większość zastrzeżeń dotyczących dopuszczenia arbitrażu w sporach dotyczących interesów kolektywu wspólników, jednakże za cenę znacznego usztywnienia ram prawnych arbitrażu"83.

\section{Rosja i inne porządki prawne}

Początkowo w braku wyraźnego postanowienia ustawy (rosyjskie prawo

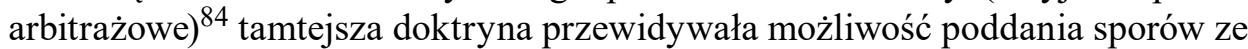
stosunku spółki kognicji sądów polubownych ${ }^{85}$. Potem jednak judykatura jednoznacznie odmówiła sporom korporacyjnym zdatności arbitrażowej. Decydujące znaczenie w tym zakresie związane jest z orzeczeniami Trybunału Konstytucyjnego Federacji Rosyjskiej oraz Najwyższego Sądu Gospodarczego Federacji Rosyjskiej. Pierwsze z nich, wydane 21 grudnia 2011 r. ${ }^{86}$, stwierdzało o szerszej właściwości sądów państwowych, niż wynika to wprost z przepisów. Zgodnie z uzasadnieniem Sądu wymienione kategorie sporów niepodlegające kognicji są-

80 A.W. Wiśniewski, op. cit., s. 252; oraz A. Anglani, F. Liguori, op. cit., s. 46-49.

81 V. Sangiovanni, Some critical observations on the Italian regulation of company arbitration, „American Review of International Arbitration” 17, 2006, nr 2, s. 286-291.

82 A.W. Wiśniewski, op. cit., s. 252; P. Biavanati, Il procedimento nell'arbitrato societario, „Rivista dell'Arbitrato” 2003, nr 1, s. 27.

83 A.W. Wiśniewski, op. cit., s. 252.

84 Arbitration Procedural Code of The Russian Federation (APC) z 24 czerwca 2002 r., no. 95-FZ, z późn. zm.

85 D. Kurochkin, V. Melnikov, Herbert Smith Dispute resolution, e-bulletin, 7.02.2012.

86 Orzeczenie Trybunału Konstytucyjnego Federacji Rosyjskiej nr VAS-1804-O-O. 
dów arbitrażowych stanowią jedynie egzemplifikację sporów otoczonych przez ustawodawcę specjalną ochroną. Z kolei w drugim z orzeczeń, wydanym 30 stycznia 2012 r. ${ }^{87}$, w słynnej sprawie Maksimov v. NLMK, Trybunał przesądził definitywnie o braku zdatności arbitrażowej wszelkich sporów korporacyjnych. Stanowisko to zostało potwierdzone uchwałą plenarną Sądu Najwyższego Federacji Rosyjskiej z 23 czerwca 2015 r., który stwierdził, że wszelkie spory wynikające ze stosunku podstawowego spółki należą do wyłącznej jurysdykcji krajowych sądów gospodarczych ${ }^{88}$.

$\mathrm{Z}$ dniem 1 lutego $2017 \mathrm{r}$. weszły jednak w życie gruntowne zmiany dotyczące zdatności arbitrażowej wprowadzone ustawami o prawie arbitrażowym w Federacji Rosyjskiej oraz o zmianie niektórych praw Federacji Rosyjskiej ${ }^{89}$, które umożliwiają poddanie większości sporów korporacyjnych (z wyjątkiem enumeratywnie ujętych odstępstw od reguły), w tym uchwałowych, kognicji sądów polubownych. Aby do tego doszło, spełnionych musi być wiele warunków formalnych określonych ustawą. Po pierwsze, wszyscy wspólnicy wraz ze spółką muszą być związani zapisem na sąd polubowny. Ponadto zapis taki musi obejmować jedynie stały sąd arbitrażowy (krajowy lub zagraniczny o ,powszechnym uznaniu i reputacji”), uznany i licencjonowany przez Federację Rosyjską ${ }^{90}$.

Nowatorskie rozwiązanie funkcjonuje tymczasem w Hiszpanii, gdzie gremium ekspertów (izby handlowe i gospodarcze, Rady Samorządów Zawodowych) opracowało model zapisu na sąd polubowny gwarantujący zapewnienie wykonalności wyrokom sądów arbitrażowych po odpowiednim włączeniu jego treści do statutu spółki.

Krańcowo odmienne podejście prezentowane jest m.in. na Ukrainie, gdzie ustawodawca w 2009 r. zdecydował o całkowitym wyłączeniu sporów korporacyjnych (w tym sporów uchwałowych) spod kognicji sądów arbitrażowych.

\section{Kraje porządku common law}

Anglosaskie kraje systemu common law, takie jak USA, Wielka Brytania, Kanada, Australia i Nowa Zelandia, cechuje liberalne podejście do kwestii zdatności arbitrażowej. W USA, szczególnie w zakresie jurysdykcji krajowej, zdatność arbitrażowa ujmowana jest wyjątkowo szeroko ${ }^{91}$. Podejście do zdatności arbitrażowej

87 Orzeczenie Najwyższego Sądu Gospodarczego Federacji Rosyjskiej nr VAS-15384/11.

${ }^{88}$ I. Kokorin, Arbitrability of corporate disputes in Russia: current and future regulation, http://www.cisarbitration.com/2016/01/18/arbitrability-of-corporate-disputes-in-russia-currentand-future-regulation/ (dostęp: 5.02.2017).

89 Zob. Cleary Gottlieb Steen \& Hamilton LLP, New Russian Rules on arbitrability of disputes, https://www.clearygottlieb.com/ /media/cgsh/files/new-russian-rules-on-arbitrability-of-disputes.pdf (dostęp: 5.02.2017).

90 Ibidem.

${ }^{91}$ K. Youssef, op. cit., s. 56. 
traktowane jest przez pryzmat ogólnych zasad dotyczących arbitrażu, a strony umowy arbitrażowej (klauzuli arbitrażowej) cieszą się przywilejami wynikającymi z ogólnej kontraktowej swobody umów ${ }^{92}$. Panuje tym samym powszechne przekonanie, poparte formułą Sądu Najwyższego ${ }^{93}$, że wszelkie wątpliwości powinny przemawiać na korzyść zdatności arbitrażowej (in favour of arbitral jurisdiction). W rezultacie amerykańskie sądy nie mają w zwyczaju podważać wyroków sądów arbitrażowych bez względu na stosunek podstawowy, z jakiego wywodzi się roszczenie ${ }^{94}$.

To swoiste domniemanie zdatności arbitrażowej (presumption of arbitrability) charakteryzuje także pozostałe jurysdykcje common law. Zarówno w Wielkiej Brytanii, jak i Australii w obliczu braku wyraźnej odpowiedzi na pytanie, czy spory korporacyjne mogą być przedmiotem postępowania przed sądem arbitrażowym, doktryna przeważnie uznaje aprioryczny brak przeszkód dla takiego rozwiązania ${ }^{95}$. Również w Kanadzie, począwszy od implementacji zasad UNCITRAL Model Law w 1986 r., Sąd Najwyższy zezwolił na szeroką ekspansję zdatności arbitrażowej, także w zakresie sporów o charakterze korporacyjnym ${ }^{96}$.

Dla jeszcze właściwszego zobrazowania podejścia systemów common law do zdatności arbitrażowej w sprawach z zakresu interesu publicznego warto przytoczyć wyrok Sądu Najwyższego Nowej Zelandii dotyczący antymonopolowych praktyk $^{97}$. Sąd stwierdził w nim bowiem, że istota i poszanowanie dla prawa i zwyczajów międzynarodowych działają na rzecz zdatności arbitrażowej nawet w tych sprawach, w których zdiagnozowano kwestie należące immanentnie do ważnego interesu publicznego.

\section{Zakończenie}

Summa summarum, podejście proarbitrażowe systematycznie staje się nurtem dominującym na arenie międzynarodowego prawa handlowego. Coraz więcej, jurysdykcja systematycznie wprowadza domniemanie zapisu na sąd polubowny bądź też rozszerza katalog spraw należących do domeny porządku publicznego posiadających mimo to zdatność arbitrażową. Już w 1999 r. Alan Redfern oraz Martin Hunter stwierdzili, że znakomita większość spraw z zakresu prawa spółek i prawa

92 I. Macneil, R. Speidel, T. Stipanowich, Federal Arbitration Law: Agreements, Awards and Remedies under the Federal Arbitration Act, Boston 1994, § 18.7.1.1.

93 Orzeczenie w sprawie Moses H. Cone Memorial Hospital v. Mercury Construction Corp., 460 U.S. 1 (1983).

94 J.T. McLaughlin, Arbitrability: current trends in the United States, „Arbitration International" 12, 1996, z. 2, s. 113.

95 J. Kerr, Arbitrability of securities law claims in common law nations, „Arbitration International" 12, 1996, z. 2, s. 171-178.

96 K. Youssef, op. cit., s. 60.

97 Orzeczenie w sprawie Attorney General of New Zealand v. Mobil Oil New Zealand Ltd. [1989], 2 NZLR 668. 
handlowego (do jakich niewątpliwie należą spory korporacyjne) posiada zdatność arbitrażową, a tendencje międzynarodowe miały doprowadzić do jeszcze większej liberalizacji w tym zakresie.

Na przestrzeni ostatnich lat liberalny trend spowodował praktyczną ,śmierć niezdatności arbitrażowej" (the death of inarbitrability), zarówno w przypadku krajów porządku common law, jak i poszczególnych państw systemu kontynentalnego (Niemcy, Szwajcaria, Francja, Włochy). W większości tych państw tzw. spory uchwałowe mogą być ogólnie poddane pod rozstrzygnięcie sądownictwu arbitrażowemu, co jest podejściem powszechnie pożądanym przez międzynarodowy kapitał oraz licznych przedstawicieli doktryny, a tym samym z powodzeniem mogłoby posłużyć polskiemu ustawodawcy do zdecydowanego i ostatecznego rozstrzygnięcia kwestii zdatności arbitrażowej.

Należy podkreślić, że polska nowelizacja Kodeksu postępowania cywilnego z 2005 r. ${ }^{98}$ nie zrealizowała przy tym swojego głównego celu, jakim była efektywna implementacja regulacji modelowej UNCITRAL ${ }^{99}$. Jak twierdzi większość komentatorów, wskazana reforma dokonana została wadliwie, a recepcja regulacji modelowej nie została przeprowadzona całościowo ${ }^{100}$. Przede wszystkim wskazuje się tu wadliwe uregulowanie niezwykle istotnych kwestii zdatności arbitrażowej (tzw. objective arbitrability) oraz problematykę sporów między wielopodmiotowymi stronami (tzw. multi-party disputes) ${ }^{101}$. Andrzej Szumański mówi tu wręcz wprost „o oportunizmie ustawodawcy”, który doskonale zdając sobie sprawę z podnoszonych w doktrynie wątpliwości, postanowił pozostawić niejasne i abstrakcyjne przepisy do konkretyzacji judykaturze ${ }^{102}$. Polski system prawny nie przystaje w tym względzie do nowoczesnych i liberalnych rozwiązań światowych. Wskazuje się tu przede wszystkim, że regulacja polska jest nadzwyczaj restrykcyjna na tle państw Unii Europejskiej. Samo kryterium zdatności ugodowej wydaje się dość surowe, a jeżeli nawet zdarza się je stosować, poszczególni ustawodawcy ograniczyli je do sporów o prawa niemajątkowe (system niemiecki, austriacki) ${ }^{103}$. Komentatorzy zwracają zresztą uwagę, że brzmienie polskiego przepisu regulującego zdatność arbitrażową jedynie pozornie nawiązuje do rozwiązań niemieckich (art. $1030 \S 1 \mathrm{ZPO}$ ) i austriackich (art. $582 \S 1 \mathrm{ZPO}$ ), znanych tradycyjnie z braku

98 Ustawa z dnia 28 lipca 2005 r. o zmianie ustawy — Kodeks postępowania cywilnego (Dz.U. z 2005 r. Nr 178, poz. 1478) weszła w życie 17 października 2005 r., dodając do k.p.c. część piątą, dotyczącą sądownictwa polubownego.

99 M. Orecki, op. cit., s. 198.

100 A.W. Wiśniewski, op. cit., s. 115-117.

101 A. Szumański, Kierunki zmian ustawodawstwa UNCITRAL o międzynarodowym arbitrażu handlowym, PPH 2007, nr 1, s. 56.

102 A. Szumański, Przeszkody prawne $w$ przyjęciu kognicji sądów arbitrażowych $w$ sporach o zaskarżanie uchwał zgromadzeń spótek kapitałowych (uwagi de lege lata oraz de lege ferenda), niepubl., s. 5.

103 R. Sikorski, op. cit., s. 47. 
ufności względem kwestii arbitrażowych ${ }^{104}$. Nawet wskazane państwa przyjmują jednak całkowite wyabstrahowanie pojęcia zdatności arbitrażowej sporów od kryterium zdatności ugodowej, nie stosując go ogólnie do sporów o prawa majątkowe. Prowadzi to do dość absurdalnej sytuacji, w której systemy germańskie, z jakich wywodzi się i czerpie nasze prawo, uchodzą za znacznie bardziej liberalne w porównaniu z polskim porządkiem prawnym. Zamiast więc czerpać z dobrego doświadczenia i praktyki zachodnich sąsiadów, a jednocześnie nadrabiać zaległości wynikające z przerwy w rozwoju prawa gospodarczego z czasów komunistycznych, ustawodawca polski robi krok w tył, interpretując wręcz na opak wcale już przecież niemłode, światowe trendy.

Biorąc pod uwagę, że w zakresie reżimu prawa handlowego polski system wywodzi się z niemieckiego, analiza rozwiązań niemieckich znajduje szczególne miejsce w rozważaniach nad zdatnością arbitrażową sądów polubownych w Polsce. Na wielu płaszczyznach wyprzedzają one regulacje rodzime, a stopniowe przyznawanie zdatności arbitrażowej sporom uchwałowym w Niemczech można śmiało uznać za projekcję drogi, jaką w najbliższym czasie może podążyć nasz ustawodawca. Pośród postulatów de lege ferenda wskazuje się, po pierwsze, na wyciągnięcie sporów majątkowych spod kryterium zdatności ugodowej w art. 1157 k.p.c. Po drugie, proponowana jest zmiana treści przepisu art. 1163 k.p.c. poprzez rozszerzenie zakresu podmiotowego o członków organów spółek kapitałowych, co doprowadziłoby do zlikwidowania niezdrowego dualizmu jurysdykcyjnego. Już samo szybkie i zdecydowane podjęcie przez ustawodawcę tych dwóch niezbędnych kroków prowadziłoby w prostej linii do opracowania przez Sąd Arbitrażowy przy KIG analogicznych rozwiązań do tych zawartych w DIS-SRCoLD, z niewątpliwą korzyścią dla spółek i innych uczestników obrotu gospodarczego.

\section{Bibliografia}

Anglani A., Liguori F., Italy's new arbitration laws, „The European Arbitration Review” 2007, http:// globalarbitrationreview.com/edition/1000463/the-european-arbitration-review-2017.

Biavanati P., Il procedimento nell'arbitrato societario, „Rivista dell'Arbitrato” 2003, nr 1.

Born G.B., International Commercial Arbitration, Alphen aan den Rijn 2009.

Bredow J., Arbitrating Shareholder Resolution Disputes in Germany: The New DIS-Supplementary Rules for Corporate Law Disputes ('DIS-SRCoLD'), [w:] Ksiega pamiatkowa 60-lecia Sadu Arbitrażowego przy Krajowej Izbie Gospodarczej, red. J. Okolski et al., Warszawa 2010.

Brekoulakis S.L., On arbitrability: Persisting Misconceptions and New Areas of Concern, [w:] Arbitrability: International and Comparative Perspectives, L.A. Mistelis, S.L. Brekoulakis, Alphen aan den Rijn 2009.

Budniak A., Charakter prawny oraz dopuszczalność zawarcia zapisu na sąd polubowny w prawie polskim i niemieckim, cz. II, „Rejent” 2008, nr 10.

Buonaiuti F.M., L'arbitrabilita delle controversie nella riforma del diritto societario, tra arbitrato interno e arbitrato internazionale, „Rivista dell“Arbitrato” 2003, nr 1.

104 W. Jurcewicz, C. Wiśniewski, op. cit., s. 26. 
Ciszewski J., Ereciński T., Kodeks postępowania cywilnego. Komentarz. Cz. 4, przepisy z zakresu międzynarodowego postępowania cywilnego. Cz. 5, sąd polubowny (arbitrażowy), Warszawa 2006.

Cleary Gottlieb Steen \& Hamilton LLP, New Russian Rules on arbitrability of disputes, https:// www.clearygottlieb.com/ /media/cgsh/files/new-russian-rules-on-arbitrability-of-disputes.pdf.

Di Pietro D., General Remarks on Arbitrability under the New York Convention, [w:] Arbitrability: International and Comparative Perspectives, red. L.A. Mistelis, S.L. Brekoulakis, „International Arbitration Law Library" 19, Austin 2009.

Fremuth-Wolf A., [w:] Arbitration Law of Austria: Practice and Procedure, red. S. Riegler, New York 2007.

Gaillard E., Edelstein J., [w:] Practitioner's Handbook on International Commercial Arbitration, red. F.B. Weigand, München 2002.

Gaillard E., France adopts new law on arbitration, „New York Law Journal” 245, 24.01.2011, nr 15.

Jurcewicz W., Wiśniewski C., Zdatność arbitrażowa sporów korporacyjnych - perspektywa polska, „Przegląd Prawa Handlowego” 2015, nr 10.

Kerr J., Arbitrability of securities law claims in common law nations, „Arbitration International” 12, 1996, z. 2.

Kokorin I., Arbitrability of corporate disputes in Russia: current and future regulation, http://www. cisarbitration.com/2016/01/18/arbitrability-of-corporate-disputes-in-russia-current-and-future-regulation/.

Koller C., Par. 3/90, [w:] Schiedsverfahrensrecht, red. C. Liebscher, P. Oberhammer, W.H. Rechberger, Wien 2011.

Kos R., Zdatność arbitrażowa sporów o ważność uchwat spótek kapitałowych, „Przegląd Prawa Handlowego" 2014, nr 3.

Kurochkin D., Melnikov V., Herbert Smith Dispute Resolution, e-bulletin, 7.02.2012.

Lew J.D.M., Mistelis L.A., Kröll S.M., Comparative International Commercial Arbitration, The Hague-London-New York 2003.

Macneil I., Speidel R., Stipanowich T., Federal Arbitration Law: Agreements, Awards and Remedies under the Federal Arbitration Act, Boston 1994.

McLaughlin J.T., Arbitrability: current trends in the United States, „Arbitration International” 12, 1996, z. 2.

Orecki M., Polskie przepisy o sądzie polubownym (arbitrażowym) - uwagi de lege ferenda, „Polski Proces Cywilny" 2014, nr 2.

Pitkowitz N., Die Aufhebung von Schiedssprüchen, Verschiedenes, Wien 2008.

Pörnbacher K., Baur S., [w:] K.L. Mehrbrey, Handbuch Gesellschaftsrechtliche Streitigkeiten, Köln 2013

Pörnbacher K., Dolgorukow A., Zdatność arbitrażowa sporów korporacyjnych (o zaskarżanie uchwat) - perspektywa niemiecka, „Przegląd Prawa Handlowego” 2015, nr 10.

Raeschke-Kessler H., [w:] M. Habersack, P. Hommelhoff, Festschrift für Wulf Goette zum 65. Geburtstag, München 2011.

Sangiovanni V., Some critical observations on the Italian regulation of company arbitration, „American Review of International Arbitration" 17, 2006, nr 2.

Schnyder A.K., Das neue IPR-Gesetz, Zürich 1990.

Schwedt K., Die praktische Umsetzung der BGH-Urteile Schiedsfähigkeit I und II, „Zeitschrift für Schiedsverfahren (SchiedsVZ)" 2010.

Sikorski R., Zagadnienia ogólne, [w:] Diagnoza arbitrażu. Funkcjonowanie prawa o arbitrażu i kierunki postulowanych zmian, red. B. Gessel-Kalinowska vel. Kalisz, Wrocław 2014.

Suliński G., Zdolność ugodowa sporów o zaskarżanie uchwat spółek kapitałowych, „ADR. Arbitraż i mediacja" 2014, nr 3.

Studenckie Prace Prawnicze, Administratywistyczne i Ekonomiczne 21, 2017

(C) for this edition by CNS 
Szumański A., Dopuszczalność kognicji sądu polubownego w sprawach o zaskarżanie uchwał zgromadzeń spótek kapitałowych, [w:] Rozprawy prawnicze. Księga pamiątkowa Profesora Maksymiliana Pazdana, red. L. Ogiegła, W. Popiołek, M. Szpunar, Kraków 2005.

Szumański A., Kierunki zmian ustawodawstwa UNCITRAL o międzynarodowym arbitrażu handlowym, „Przegląd Prawa Handlowego” 2007, nr 1.

Szumański A., Przeszkody prawne w przyjęciu kognicji sądów arbitrażowych w sporach o zaskarżanie uchwat zgromadzeń spótek kapitałowych (uwagi de lege lata oraz de lege ferenda), niepubl.

Viscasillas M.P.P., Arbitrability of (Intra-) Corporate Disputes, [w:] Arbitrability: International and Comparative Perspectives, red. L.A. Mistelis, S.L. Brekoulakis, „International Arbitration Law Library" 19, Austin 2009.

Walter G., Busch W., Brönnimann J., Internationale Schiedsgerichtsbarkeit in der Schweiz, Berno 1991.

Wiśniewski A.W., Międzynarodowy arbitraż handlowy w Polsce. Status prawny arbitrażu $i$ arbitrów, Warszawa 2011.

Youssef K., The Death of Inarbitrability, [w:] Arbitrability: International and Comparative Perspectives, red. L.A. Mistelis, S.L. Brekoulakis, „International Arbitration Law Library” 19, Austin 2009 .

\section{Akty prawne}

Arbitration Procedural Code of The Russian Federation (APC) z 24 czerwca 2002 r., no. 95-FZ, z późn. zm.

Dekret Ministra Sprawiedliwości z dnia 13 stycznia 2011 r., nr 2011-48, portant reforme de l'arbitrage, NOR: JUSC1025421D, zmieniający w całości Księgę IV francuskiego Kodeksu postępowania cywilnego.

DIS-Supplementary Rules for Corporate Law Disputes 09 (SRCoLD) obowiązujące od 16 września 2009 r., http://disarb.org/de/16/regeln/dis-supplementary-rules-for-corporate-law-disputes09-srcold-id15.

Kodeks cywilny Francji, https://www.legifrance.gouv.fr/content/download/1950/13681/version/3/ file/Code_22.pdf.

Konwencja europejska o międzynarodowym arbitrażu handlowym, sporządzona w Genewie dnia 21 kwietnia 1961 r. (Dz.U. z 1964 r. Nr 40, poz. 270).

Konwencja o uznawaniu i wykonywaniu zagranicznych orzeczeń arbitrażowych, sporządzona w Nowym Jorku dnia 10 czerwca 1958 r. (Dz.U. z 1962 r. Nr 9, poz. 42).

German Arbitration Act, oparta na ustawie modelowej UNCITRAL, http://sccinstitute.com/media/29988/german-arbitration-act.pdf.

Niemiecki kodeks postępowania cywilnego (Zivilprozessordnung/Zivilverfahrensgesetzbuch, ZPO), https://www.gesetze-im-internet.de/bundesrecht/zpo/gesamt.pdf.

Swiss Private International Law Statute (1990), http://mitchellhamline.edu/wp-content/uploads/sites/18/2016/05/DOC-10-Swiss-Private-International-Law-Statute.pdf.

Ustawa modelowa o międzynarodowym arbitrażu handlowym uchwalona przez UNCITRAL w 1985 r., ze zmianami z 2006 r., http://www.uncitral.org/pdf/english/texts/arbitration/ml-arb/0786998 Ebook.pdf.

Ustawa z dnia 17 listopada 1964 r. — Kodeks postępowania cywilnego, tekst jedn. (Dz.U. z 2014 r. poz. 101 z późn. zm.).

Ustawa z dnia 28 lipca 2005 r. o zmianie ustawy — Kodeks postępowania cywilnego (Dz.U. z 2005 r. $\mathrm{Nr} 178$, poz. 1478).

Ustawa z dnia 1 lipca 2006 r., zmieniająca art. 577-618 austriackiego Kodeksu postępowania cywilnego (ZPO), Schiedsrechts Änderungsgesetz 2006, BGB1 I 2006/7. 


\section{Orzecznictwo}

Orzeczenie Najwyższego Sądu Gospodarczego Federacji Rosyjskiej nr VAS-15384/11.

Orzeczenie Swiss Federal Tribunal z dnia 23 czerwca 1992 r. w sprawie Fincantieri-Cantieri Navali Italiani SpA v. M and Arbitration Tribunal, XX YBCA 766 (1995).

Orzeczenie Trybunału Konstytucyjnego Federacji Rosyjskiej nr VAS-1804-O-O.

Orzeczenie w sprawie Attorney General of New Zealand v. Mobil Oil New Zealand Ltd. [1989], 2 NZLR.

Orzeczenie w sprawie Moses H. Cone Memorial Hospital v. Mercury Construction Corp., 460 U.S. 1 (1983).

Uchwała SN z dnia 7 maja 2009 r., sygn. III CZP 13/09, OSNC 2010/1/9.

Wyrok OGH z dnia 3 czerwca 1950 r., docket no. 2 Ob 276/50.

Wyrok OGH z dnia 10 października 1999 r., docket no. 7 Ob 221/98w, RdW 206 (1999).

Wyrok OGH z dnia 3 kwietnia 2001 r., docket no. 4 Ob 37/01x, ecolex 350 (2001).

Wyrok OGH z dnia 29 czerwca 2006 r., docket no. 6 Ob 145/06a, RdW 588 (2006).

Wyrok OGH z dnia 22 października 2010 r., docket no. 7 Ob 103/10p, GeS. 276 (2010).

Wyrok OGH z dnia 19 kwietnia 2012 r., docket no. 6 Ob 42/12p, GeS 388 (2012).

Wyrok OGH z dnia 8 maja 2013 r., docket no. 6 Ob 47/13z, RS0045066.

Wyrok Sądu Krajowego w Hamm z dnia 8 grudnia 1986 r., sygn. 8 U 73/86, NJW-RR 1987.

Wyrok Trybunału Federalnego z dnia 4 lipca 1951 r., sygn. II ZR 117/50, MDR 1951.

Wyrok Trybunału Federalnego z dnia 11 lipca 1966 r., sygn. II ZR 134/65, NJW 1966.

Wyrok Trybunału Federalnego z dnia 29 marca 1996 r. sygn. II ZR 124/95, NJW 1996.

Wyrok Trybunału Federalnego z dnia 6 kwietnia 2009 r., sygn. II ZR 255/08, BGHZ 180.

\section{Objective arbitrability of intra-corporate disputes in foreign legal systems}

\section{Summary}

In conclusion, the arbitration - friendly approach is systematically becoming the dominant trend in the international commercial law arena. More and more jurisdictions are introducing a presumption of arbitration clause or extending the catalog of public domain law matters that still have arbitration. As early as 1999, A. Redfern and M. Hunter argued that the vast majority of corporate and commercial law cases (which undoubtedly include intra-corporate disputes) have objective arbitrability. By this time, international tendencies have led to even more liberalization in this field and eventually, over the last few years, the liberal trend has led to the practical "death of inarbitrability", both in the common law systems and in the continental ones (like in Germany, Switzerland, France, Italy). In most of these countries, the so-called intra-corporate disputes can generally be submitted to the arbitration court, which is an approach universally desired by international capital and numerous representatives of the doctrine, and thus could successfully serve the Polish legislator to definitively find a solution for this controversial issue. 